\title{
Pasture weed biology and management in Brazil
}

\section{Biologia e manejo de plantas daninhas em pastagens no Brasil}

\author{
Dagoberto Martins ${ }^{1}$; Sidnei Roberto de Marchii ${ }^{2}$ : Ricardo Fagundes Marques ${ }^{3 *}$
}

\section{Highlights}

Knowledge of the biology of pasture weeds is crucial for livestock production.

The presence of weeds directly affects forage grasses in Brazil.

Some pasture weeds in Brazil have ruderal characteristics.

The use of herbicides is crucial to the control of eudicotyledon weeds.

There are few alternatives for the control of invasive grasses in pastures.

\begin{abstract}
The livestock production model historically practiced in Brazil has a strong extractive bias, wherein the premise is to produce livestock with absolutely no concern for the preservation or renewal of environmental resources. The absence of technical criteria for the use of pastures has generated low productivity rates, making the activity unsustainable from both economic and environmental points of view. This scenario led the several sectors linked to the production chain to develop a package of strategies to solve the problems faced by livestock farmers. This package of strategies is conventionally called postmodern or corporate farming, in which the extractive process gives way to the business logic of avoiding waste and recovering profit margins mainly through pasture perpetuation. However, there is still a technical gap in corporate cattle farming related to problems caused by pasture weeds because all the concepts applied are derived or copied from concepts generated in agriculture. Furthermore, few researchers have studied or scientific articles written on elucidating the real problem of weeds in livestock production. Thus, the goal of the present review was to present some aspects related to weed ecology, their interference, and management alternatives in pasture areas, thereby collaborating with corporate livestock farming in Brazil because solutions to weed problems are crucial to increase commitment in all sectors of the production chain.
\end{abstract}

Key words: Forage. Phytosociological indices. Weed interference. Control methods.

1 Prof. Dr., Universidade Estadual "Júlio de Mesquita Filho", Faculdade de Ciências Agrárias e Veterinárias, UNESPFCAV, Jaboticabal, SP, Brazil. E-mail: dagoberto.martins@unesp.br

2 Prof. Dr., Universidade Federal de Mato Grosso, Campus do Araguaia, UFMT, Barra do Garças, MT, Brazil. E-mail: sidneimarchi.ufmt@gmail.com

${ }^{3}$ Doctoral Student of the Postgraduate Program in Agronomy (Plant Production), UNESP-FCAV, Jaboticabal, SP, Brazil. E-mail: rfmarques94@gmail.com

* Author for correspondence

Received: Mar. 24, 2021 - Approved: Nov. 10, 2021 


\section{Resumo}

O modelo de atividade pecuária historicamente praticado no Brasil está alicerçado, em sua grande maioria, em forte viés extrativista, onde a premissa é produzir sem absolutamente nenhuma preocupação quanto à preservação ou renovação dos recursos ambientais. A ausência de critérios técnicos na utilização das pastagens gerou e ainda gera baixos índices de produtividade e torna a atividade insustentável do ponto de vista econômico e ambiental. Tal cenário levou os diversos setores ligados à cadeia produtiva a desenvolver um pacote de estratégias visando solucionar os problemas enfrentados pelos pecuaristas. A esse pacote de estratégias convencionou-se chamar de pecuária pós-moderna ou empresarial, onde o processo extrativista cede lugar à lógica empresarial de evitar desperdícios e recuperar as margens de lucros através, principalmente, da perenização das pastagens. Entretanto, ainda existe uma lacuna técnica na pecuária empresarial referente aos problemas ocasionados pelas plantas daninhas em áreas de pastagem, uma vez que todos os conceitos aplicados são provenientes ou copiados daqueles conceitos gerados na agricultura. Além disso, são raros os pesquisadores e artigos científicos dedicados à compreensão da real problemática das plantas daninhas na atividade de produção animal. Assim, a presente revisão tem como objetivo apresentar alguns aspectos ligados à ecologia de plantas daninhas, sua interferência e alternativas de manejo em áreas de pastagens, visando, dessa forma, colaborar com a pecuária empresarial no Brasil, uma vez que soluções para o problema da ocorrência de plantas daninhas é um ponto crucial para proporcionar aumento do empenho em todos os setores da cadeia produtiva.

Palavras-chave: Forragem. Índices fitossociológicos. Matointerferência. Métodos de controle.

\section{Introduction}

National livestock farming practiced between the early 1900 s and the 1970s is known as traditional, characterized by stunted cattle with long horns, low carcass yield, and raised free in unfenced areas covered with grass with low nutritional value. The phase of livestock farming modernization lasted from the 1970s to mid-2000s, characterized by genetic improvement of the herd, improved pastures with the introduction of grasses of African origin, and the implementation of new management techniques whose main objective was to ensure high animal productivity (M. B. Dias, 2016; T. B. Carvalho \& De Zen, 2017).

Despite advances in animal production efficiency, on several occasions, the so-called modern cattle farming still proved ineffective from the financial point of view. Thus, a new vision in Brazilian cattle farming began in the 2000s and focused on farm management with the goal of profits and not only animal farming. Additionally, this new vision sought to establish directrelationshipsand links between the cattle farmer and slaughterhouses or supermarket chains; thus, increasing the bargaining power of the producer and giving them the right to participate in profit sharing in the production chain. This new vision is called postmodern or corporate cattle farming, and it is important to note that the sector is still divided between traditional or modern models, presenting slow but growing adherence to the business model (J. C. Teixeira \& Hespanhol, 2014; Strassburg et al., 2014; M. C. Santos, Belik, De Zen, \& Almeida, 2014; Pereira, 2015).

The Brazilian agricultural and livestock sector occupies an area of approximately 350 
million hectares, which are mainly used for the forestry, agriculture, and livestock production chains. Importantly, approximately 165 million hectares of this area are allocated to natural $(73,569,000 \mathrm{ha})$ or cultivated $(91,456,000$ ha) pastures, whereas fields cultivated with grains total only $64,099,000$ ha (Parente Mesquita, Miziara, Baumann, \& Ferreira, 2019). Similar to that observed in agriculture, the pasture ecosystem is highly dynamic, with the mechanisms and processes involved in the production, harvest, and transformation of forage into animal products being integrated and compensatory. This hinders the achievement of positive net results from isolated actions in any compartment of the production system (M. E. R. Santos, 2011; R. M. Carvalho, Pimentel, Fonseca, \& Santos, 2016). To achieve satisfactory production rates and enable livestock production characterized by a shorter cycle in search of greater economic efficiency, animal feeding cannot become an obstacle to obtaining these objectives (Gléria, Silva, Santos, Santos, \& Paim, 2017).

In most Brazilian livestock production systems, the animals harvest the pasture, using specific strategies to meet their nutritional needs. Thus, it has been experimentally demonstrated that animals exhibit certain wisdom when choosing food, such that the grazing habits practiced ensuring the balance of nutrients for their maintenance (E. A. Teixeira, Marques, Silva, \& Pires, 2010; Mezzalira et al., 2001).

Herbivores have developed some mechanisms that allow selective food choice in grazing environments. The consequence of selective grazing is the increased heterogeneity of pasture structure, with plant species that are not palatable prevailing over those frequently consumed by the animals, besides favoring the establishment of a gradual pasture degradation process (P. C. F. Carvalho, Santos, \& Neves, 2007; Zanine, Vieira, Ferreira, Vieira, \& Cecon, 2007; M. E. R. Santos, 2011; W. T. V. Carvalho et al., 2017; Marchi, Silva, Ferreira, Marques, \& Moraes, 2019a).

It is noteworthy that pasture degradation is one of the main cattle farming problems in Brazil, with estimates that approximately $51 \%$ of these areas are in the degradation process (Terra, Florentino, Rezende, \&Silva, 2019). The process of pasture degradation is a complex phenomenon that involves causes and consequences that lead to the gradually decreased support capacity of the pasture. Several factors can favor the degradation process, such as the mistaken choice of forage species, the high rate of animal stocking, and the lack of soil nutrient replacement. The consequences are a drastic reduction in the height of the forage canopy, a decreased area covered by pasture soil, and the appearance of plant species not grazed by animals, which are thus considered weeds (M. B. Dias, 2011; W. T. V. Carvalho et al., 2017; A. Silva, Santos, Barretto, Freitas, \& Kluthcouski, 2018).

However, weeds are not the cause of degradation but rather the inadequate management of extractive cattle farming historically implemented in Brazilian pastures. When installed, weeds negatively interfere with the structure of the forage canopy and the grazing habit of animals (Marchi, Bellé, Foz, Ferri, \& Martins, 2017; Bellé, Marchi, Martins, Sousa, \& Pinheiro, 2018; Lourenço, Mota, Sanches, Marques, \& Marchi, 2019; Marchi et al., 2019b; R. F. Marques et al., 2019; Araújo, Marques, Pinheiro, Souza, \& Marchi, 2020), consequently causing economic losses 
throughout the livestock production chain, pressuring for the opening of new extensive pasture areas (Andrade, Bolfe, Victória, \& Nogueira, 2017), in addition to contributing to increased greenhouse gas emissions because of the supply of food with low nutritional value to the animals (Lourenço et al., 2019; Marchi et al., 2019b; Meurer, Brito, Marchi, Pinheiro, \& Martins, 2020).

The goal of this review is to present some aspects of weed ecology, their interference, and management alternatives in pasture areas, collaborating with the production chain of traditional, modern, and corporate livestock in Brazil.

\section{Phytosociological indices}

Weed communities in agroecosystems present plant populations that coexist with competitive and allelopathic processes and are linked to biotic and abiotic components of the environment, transforming the importance of a population into an indicator of soil-climatic conditions and agricultural practices (Pitelli, \& Bianco, 2013). Phytosociological parameters commonly used in botanical inventory analysis studies are: frequency (Fre) = number of plots containing the species/total number of plots used; density (Den) $=$ total number of individuals per species/total area collected; abundance $(\mathrm{Abu})=$ total number of individuals per species/total number of plots containing the species; relative frequency (Frr) = frequency of the species $\times 100 /$ total frequency of all species; relative density (Der) $=$ density of the species $\times 100 /$ total density of all species; relative abundance $(\mathrm{Abr})=$ abundance of the species $\times 100 /$ total abundance of all species; and importance value index (IVI) $=\mathrm{Frr}+\mathrm{Der}$
+ Abr (Mueller-Dombois, \& Ellenberg, 1974; Braun Blanquet, 1979; Pitelli, \& Bianco, 2013).

It is important to understand these indices because in many cases, they are mentioned in the discussion of the results of weed communities in different studies on the floristic surveys in pastures to establish the importance of the species in these communities.

\section{Weed surveys}

Brazil presents distinct soil-climatic conditions because of its continental dimension, with a milder climate in the south (sub-tropical) and warmer in the north (tropical). This fact influences the composition of weed communities that occur both in natural and implemented pastures. However, an ecological factor is common to all areas: low soil disturbance and overall low disturbance in these environments. Grime (1979), who proposed the evolutionary strategies of plant adaptation on the planet, showed that most weeds present in this agroecosystem would be classified as "competitors" because they tolerate a low intensity of disturbance and stress, being positioned at intermediate stages of succession, examples being: Vernonia polyanthes Less (assa-peixe), Vernonia scabra Pers. (assa-peixe), Acassia plumosa Lowe Less (arranha-gato), Lantana camara L. (lantana), and Peschiera fuchsiaefolia Miers. (milkweed) (S. L. Carvalho \& Pitelli, 1992; R. E. Mascarenhas, Modesto, Dutra, Souza, \& Teixeira, 1999; C. C. Martins, Martins, Negrisoli, \& Stanguerlim, 2000; Modesto, \& Mascarenhas, 2001; Dias et al., 2018).

However, some weeds, depending on pasture quality, age, and grazing, would 
have ruderal characteristics for withstanding high-intensity disturbance, such as intense grazing, fire, and weeding, but with low-stress intensity. This group includes species, such as Acanthospermum australe (Loefl.) Kuntze (carrapicho-rasteiro), Portulaca oleracea L. (beldroega), Bidens pilosa L. (picão-preto), and Amaranthus hybridus L. (caruru) (Brandão et al., 1995; S. L. Carvalho \& Pitelli, 1992; R. C. Dias et al., 2018).

Phytosociological surveys in Brazil are still scarce, and sometimes in areas that are not very representative and with highly different degrees of scientific acuity, besides the fact that many studies are extremely old. There are surveys conducted in the following regions and states: north region, in Amazonas (L. B. Teixeira, Canto, \& Homma, 1973; Dantas, 1979; Galvão, Silva, Albertino, Monteiro, \& Calvalcante, 2011) and Pará (R. E. Mascarenhas et al., 1999; Modesto \& Mascarenhas, 2001); center-west, in Mato Grosso do Sul (S. L. Carvalho \& Pitelli, 1992); southeast, in Rio de Janeiro (Peixoto, Carvalho, \& Rosa, 1982; Brandão et al., 1995) and in Minas Gerais (Tuffi Santos et al., 2004; M. H. T. Mascarenhas, Viana, Lara, Botelho, \& Morel, 2009; M. V. Santos et al., 2015; R. C. Dias et al., 2018).

In a study described in a technical circular of Embrapa-Manaus (IPEAAOc) in the early 1970s, L. B. Teixeira et al. (1973) described weed management in two pastures: Jaraguá (Hyparrthenia rufa [Nees] Stapf.) and braquiária (Brachiaria decumbens Stapf.) in the city of Manaus (AM). The following weed species were found in both pastures: Spermacoce verticillata L. (vassourinha-debotão), Solanum grandifolium Ruiz \& Pav. (lobeira), Trema micranta (L.) Blume (corindiba), Solanun rugosum Dunal (amor-de-cunhã), Stachytarpheta cayannensis (Rich.) Vahl (rinchão), Solanum caavurana Vell. (wild tomato tree), and Perebea mollis (Poepp \& Endl.) Huber (Cauchorana), which are native to Brazil and common in the Amazon region.

Dantas (1979) conducted a survey in the city of Itacoatiara (AM) with another pasture species (Setaria sp.) and identified the occurrence of 19 botanical families containing weed species. The Solanaceae family was the most important with nine species, and among these, Solanum toxicarium Lam. (jurubeba) was the most abundant in the study area. The species S. rugosum and S. grandifolium were also found in a previous study by L. B. Teixeira et al. (1973), and Manaus is $269 \mathrm{~km}$ from Itacoatiara.

Thirty-eight years after the study by Dantas (1979) in Amazonas, there was a new study on pasture phytosociology in two seasonal floodplain areas in the city of Autazes (AM) conducted by Galvão et al. (2011). They found 12 botanical families and 22 plant species. The most important families in species number in both areas and higher frequencies, abundances, densities, and importance value indexes (IVI) were Poaceae with seven species and Cyperaceae with four species. Brachiaria subquadripara (Trin.) Hitchc. (tanner grass) had the highest IVI, and the Poaceae family represented more than $90 \%$ of the individuals recorded in both areas.

The species found only in Area 1 were: Astrocaryum gynacanthum Mart. (mumbaca), Cyperus sphacetalus Rottb. (peri), Croton glandulosus L. (gervão), Eleusine indica (L.) Gaertn. (goosegrass), Ludwigia palustris (L.) Elliot, Pontederia rutundifolia L. (mureré), Setaria parviflora (Poir.) Kerguélen (knotroot foxtail); and those only in Area 2 were: Acroceras zizanioides (Kunth) Dandy, 
Ambrosia artemisiifolia L. (artemija), Cyperus compressus L. (annual sedge), Fimbristylis dichotoma(L.)Vahl(forked frimbry), and Justicia pectoralis Jaq.; with both areas presenting: Aeschynomene fluitans Peter, Alternanthera philoxeroides (Mart.) Griseb (alligator weed), B. subquatripara, Diodia Kuntzei (K.) Schlum., Fimbrystilis miliacea (L.) Vahl (cumin), Lindernia crustacea (L.) muell. (canga), Panicum laxumSw. (capim-taboquinha), Paspulum fasciculatum Willd. Ex Flüggé (capim-morí), and Cynodon dactylon (L.) Pers. (grama-seda). For similarity, regardless of the index used, Jaccard $(S j=41)$ or Sorensen $(\mathrm{Si}=58$ ), the areas were similar according to index ranges of Muller-Dombois \& Ellenberg (1974). Areas were considered similar when they had a Jaccard index greater than 25 or a Sorensen index greater than 50 . Most of these species are from flooded areas and not found in upland pastures; thus, there was a lack of studies in these conditions because cattle farming in upland areas was well developed. Of the species found in this study, only $P$. laxum was also identified in the study by Dantas (1979), which may be related to the flooded environment studied there, which was different from that of the first study conducted on uplands.

In a study conducted in Terra Alta, PA, Modesto and Mascarenhas (2001) surveyed the weed community in a degraded Brachiaria humidicola (Rend.) Scheich. (capim-quicuio) pasture aged 10 years. The individuals found were distributed in 17 botanical families and 36 species. The most abundant families were Poaceae and Rubiaceae, with five species each, followed by Leguminosae, with four, and Asteraceae and Solanaceae, both with three species. The weeds that presented greater importance in the community were: Borreria verticillata (L.) G.F.W. Mey (buttonweed),
Hyptis atrorubens Poit (bushmints), Rolandra argentea Rottb. (acarycoá), Desmodium incanum DC. (creeping beggarweed), Panicum pilosum SW. (capim-de-anta), Davilla rugosa Poir. (cipó-de-fogo), Imperata brasiliensis Trin. (Brazilian satintail), Paspalum maritimum Trin. (crowngrass), Vernonia scorpioides Pers. (enxuga), and Vismia guianensis (Aublet) Choisy (lacre).

There was a technical publication by Embrapa-Belém that listed the main species occurring in pastures in the Eastern Amazon, but it did not mention the scientific studies in the information used to compile the list of plants (R. E. Mascarenhas et al., 1999). Part of the surveys presented is mentioned in a study by Modesto and Mascarenhas (2001).

Several surveys were conducted in Rio de Janeiro, but many were described in congress annals, mimeographed handouts, technical bulletins, and in only two verifiable and acceptable scientific articles (Peixoto et al., 1982; Brandão et al., 1995). However, Brandão et al. (1995) used these abovementioned sources without scientific acuity to assemble the list of weeds occurring in pastures in Rio de Janeiro. Peixoto et al. (1982) conducted surveys in several pastures and recorded species, including Panicum maximum Jacq. (Guinea grass), Pennisetum purpureum Schum. (elephant grass), Brachiaria mutica (Forssk.) Stapf (para grass), and Brachiaria plantaginea (Link) Hitchc. (gyemsa), which made a more in-depth analysis of the occurrence of weed species in these pastures difficult because it is a single list without specifications of the pasture in which they were found. Twenty-seven families with 67 species were inventoried, including the Poaceae family with 10 species and Asteraceae and Fabaceae with seven species each. The species with the 
highest IVI were: Sphagneticola trilobate (L.) Pruski (22.65), C. dactylon (19.19), Paspalum conjugatum Berg. (16.55), Croton urticaefolius Lam. (12.59), Sidrastrum micranthum (ST. Hil.) Fryxell (9.28), and Sida carpinifolia L. (7.73).

In Minas Gerais, phytosociological studies on pastures are more recent. Lara, Macedo and Brandão (2003) surveyed the weed community in floodplain areas of the São Francisco River in $B$. mutica pastures in the cities of Pompéu, Abaeté, Bom Despacho, Luz, Iguatama, and Martinho Campos. In all, 110 weed species were identified, belonging to 29 families. Asteraceae presented the highest number of species in all sites evaluated, followed by Malvaceae, Poaceae, and Euphorbiaceae. The most important species were $V$. polyanthes in Iguatama (IVI = 69.32); Corchorus hirtus L. (hairy jute) in Bom Despacho (IVI = 54.87); Echinochloa crusgalli (L.) Beauv. (cockspur) in Pompéu (IVI = 42.27); Ipomoea ramosissima (Poir) Choisy (campainha) in Martinho Campos (IVI = 39.13); Hypenia densiflora (Pohl ex Benth.) Harl. in Abaeté (IVI = 33.46); and Sida rhombifolia L. (arrowleaf sida) in Luz (IVI = 28.41). The similarity index calculated between the areas was low, with no species occurring in all six studied sites. Many species were exclusive to each site. Species that occurred in five sites included $V$. polyanthes, C. hirtus, and I. ramosissima.

In another flora survey conducted in Leopoldina, MG, in Zona da Mata, Tuffi Santos et al. (2004) also studied a degraded pasture under floodplain conditions in two plots with $B$. mutica and one with Setaria anceps Kazungula. The researchers recorded 27 species in 11 families in the B. mutica pasture and 34 species in 13 families in the Setaria anceps pasture. The most representative family in species was Poaceae with 11, followed by Asteraceae with six, Papilionoideae with five, and Malvaceae and Euphorbiaceae with four each, corroborating the study by Lara et al. (2003).

The IVI of some species occurring in both pastures were different, such as Mimosa pudica Linn., 18.76 in the Setaria anceps pasture, and 7.05 in B. mutica pasture. The most representative species in the $B$. mutica pasture and their respective IVIs were $S$. rhombifolia (48.82), B. mutica (46.93), and Cyperus esculentus L. (tiger nut) (33.20). In the Setaria anceps pasture, the most representative species were $S$. rhombifolia (100.13), C. dactylon (58.47), and C. esculentus (31.46). The similarity index (SI) between the two areas was $62.3 \%$, indicating medium similarity. S. rhombifolia was also the species with the highest IVI in the survey conducted by Lara et al. (2003) in a B. mutica pasture in a floodplain in the municipality of Luz, MG.

Of all the species found in the Setaria anceps grass pasture, only two (M. pudica and Amaranthus spinosus L.) were similar to those found within the same species pasture by Dantas (1979) in the state of Amazonas. When compared with the weed community surveyed by Galvão et al. (2011) in a floodplain in the state of Amazonas, only one species, $C$. dactylon, was similar, which can be justified, regardless of being floodplain areas, for being environments in different biomes (Equatorial forest (AM) and Atlantic Tropical forest (MG)).

Working in a degraded $B$. decumbens pasture under-recovery by the crop-livestock system in the municipality of Prudente de Morais, MG, M. H. T. Mascarenhas et al. (2009) recorded 18 weed species in 11 families before the implementation of the system, with 
the most important being Poaceae, followed by Fabaceae, with four and three species, respectively. After almost 1 year of work implementing the system with corn culture associated with $B$. decumbens, only three species were found in the area: $B$. decumbens (Poaceae), Sida graziovii K. Schum. (guanxuma) (Malvaceae), and Smilax brasiliensis Spreng. (chives) (Liliaceae).

Another study involved the recovery of a degraded $B$. decumbens pasture in a croplivestock-forest system involving eucalyptus, corn, and B. brizantha in Curvelo, MG, R. C. Dias et al. (2018) identified the presence of 23 weed species before the implementation of the study. After implementing the system, the species Sida cordifolia L. (guanxuma), L. Camara, and $B$. decumbens were the only ones occurring before and after pasture renovation with the system.

A phytosociological study in a molasses grass (Melilis minutiflora P. Beauv.) pasture was conducted in the municipality of Viçosa, MG, by M. V. Santos et al. (2015), who identified 31 weed species distributed in 12 families, with emphasis on the family Poaceae with eight species, and Asteraceae with seven. The species with the highest IVIs were C. esculentus (48.96), M. minutiflora (35.63), I. brasiliensis (20.24), S. graziovii (19.13), Urochloa decumbens (Stapf) R. D. Webster (10.73), and Campuloclinium macrocephalum (Less) DC. (10.47).

Only one phytosociological study was recorded in the state of Mato Grosso do Sul, which was conducted in 10 farms in Selvíria, MS, by S. L. Carvalho and Pitelli (1992). They identified 73 weed species. The researchers observed few species with widespread frequency, but the study did not discriminate the species of pasture in which these weeds occurred. The families Asteraceae and Fabaceae had the greatest number of species in the areas studied, 13 and 10, respectively, and the family Malvaceae presented the greatest plant density. The most abundant species were $S$. rhombifolia var. typica $K$. Schum and S. cordifolia. The species with the highest frequency was S. cordifolia, with $64.5 \%$ in the total area studied. The similarity coefficient for the studied areas ranged from $21.6 \%$ to $80 \%$, with these differences attributed to the soil or distance between the studied areas.

\section{Weed interference}

This section includes some basic concepts before presenting the research in the area. The forms of direct weed interference with cultivated plants are competition for growth resources, allelopathy, and parasitism (Pitelli \& Pitelli, 2004). Under field conditions, it is almost impossible to separate the effects of competitive and allelopathic actions; thus, the term interference is attributed to all the effects of living with weeds in crop, forest, and pasture land (Harper, 1977).

Studies in this area analyzed the time and duration of the periods in which the weed community could coexist with crops without damaging effects on productivity or product quality. Elucidating these periods is essential for the implementation of adequate weed management (Pitelli, 1985). This researcher emphasized that several weed factors acted on the performance of competitors, such as specific composition, density, and geographical weed distribution. Additionally, the variety, density, and geographical 
distribution of the cultivated plant in the planting area and cultural practices also had an effect, as did soil and climatic conditions in the site where the competitive interaction developed.

Pitelli and Durigan (1984) proposed designations for the periods of weed interference with crops, namely: $\mathrm{PBI}$, the period before interference, the period in which, after emergence, the cultivated plant, in this case, pasture, and the weed community can coexist without damaging production, product quality, and/or harvest; TPIP, the total period of interference prevention, which refers to weeds emerging in the crop after this period which will no longer affect the production of the cultivated plant; thus, stipulating the final period of weed control in the crop cycle; and CPIP, the critical period of interference prevention, which occurs when the $\mathrm{PBI}$ is shorter than the TPIP, requiring a longer control maintenance period, starting at the end of the $\mathrm{PBI}$ and extending to the end of the TPIP.

Unlike the studies on weed floral surveys, studies on weeds in forage and pastures are more recent but still scarce considering the size and diversity of Brazilian biomes. Most studies were conducted in the center-western region of the country (Marchi et al., 2017; Bellé et al., 2018; Lourenço et al., 2019; R. F. Marques et al., 2019b). One was conducted in the state of Rio de Janeiro (Brighenti \& Oliveira, 2018) and one in the state of São Paulo (P. F. R. B. Martins, Yamauti, \& Alves, 2018), with the latter being the only one conducted under greenhouse conditions.

In a substitute experimental model, P. F. R. B. Martins et al. (2018) studied interference relationships between $B$. decumbens and Synedrellopsis grisebachii Hieron \& Kuntze (agriãozinho), reporting the need for $16 \mathrm{~B}$. decumbens plants per pot to reach a critical population and that Synedrellopsis grisebachii was more competitive than $B$. decumbens. Studies in pots should be considered indicative, and in the case of pastures, confirmation in the field is necessary.

A study by Marchi et al. (2017) in a pasture reform with $B$. brizantha Marandú in Itaúba, MT, recorded the occurrence of only three weed species in the experimental area, H. suaveolens, Senna obtusifolia (L.) H.S. Irwin \& Barneby (sicklepod), and S. rhombifolia, when evaluating these weeds for coexistence periods ranging from 0 to $120 \mathrm{~d}$. The researchers documented decreased plant height, number of shoots, and accumulated dry matter after $15 \mathrm{~d}$ of coexistence with the weeds by approximately $50 \%$, which led to the recommendation of weed control from $15 \mathrm{~d}$ of coexistence.

As a complement, and following the study by Marchi et al. (2017), Bellé et al. (2018) evaluated the nutritional quality of the abovementioned pasture. They observed that the presence of weeds in the pasture negatively changed the morphology of $B$. brizantha plants, including the leaf-to-stem ratio and the volumetric density of green leaves by approximately $40 \%$. They also reported that as the period of coexistence of forage with the weed community increased, all nutritional components studied, such as the content of crude protein, the fiber in a neutral detergent, ethereal extract, organic and mineral matter, and total carbohydrates, were reduced and suggested that weed control should be conducted prior to $30 \mathrm{~d}$. Considering these two studies (Marchi et al., 2017; Bellé et al., 2018), it is noted that to 
maintain the maximized dry matter production and the nutritional value of the forage, the weed community should be controlled almost immediately after pasture emergence, and at most, $15 \mathrm{~d}$ after this operation.

In a weed interference study in Barra do Garças, MT in another pasture species (Urochloa ruziziensis R. Germ. \& Evrard.), Lourenço et al. (2019) reported that weed community management was also necessary at $15 \mathrm{~d}$ of coexistence (PBI) with pasture, which corroborated the behavior recorded for $B$. brizantha (Marchi et al., 2017) because the dry biomass production of the forage was already altered by coexistence at this time. In this case, the weed community was composed of more species, totaling 10: C. glandulosus; Sena obtusifolia (L.) H.S. levin \& Barneby; Glycine wightii (Woight \& Arn.) Vedc.; Mimosa debilis L.; H. suaveolens; Diodella teres (Walter) Small; Sida santaremmensis Monteiro; Spermacoce latifolia Aubl.; Waltheria americana L.; and Urena lobata $\mathrm{L}$. The latter three were the most representative in the area. It is noteworthy that, based on these few studies, S. obtusifolia and $H$. suaveolens also occurred in the study with B. brizantha (Marchi et al., 2017), and that regardless of species diversity being high or low, the coexistence period exceeding $15 \mathrm{~d}$ led to harmful effects on the pasture.

When evaluating weed interference with pasture formation with Bermuda grass (Cynodon dactylon cv. Vaquero) in Barra do Garças, MT, R. F. Marques et al. (2019b) reported that the presence of weeds negatively interfered with the leaf/stem ratio, volumetric density of green leaves, and the amount of forage produced by this grass, suggesting that control measures should be implemented prior to $3 \mathrm{~d}$ of coexistence.
A study in Valença, RJ, on weed interference of $C$. esculentus on Pennisetum purpureum Schum. (elephant grass) determined that the PBI was 23 d, i.e., the forage could coexist with the weed for this period without reducing dry mass production, and the TPIP was $42 \mathrm{~d}$, which led to the need to maintain the forage free of weeds during this entire period after sprouting. Therefore, CPIP could be from 23 to $42 \mathrm{~d}$, a period in which weeds cannot compete with the forage plants (Brighenti \& Oliveira, 2018). Because this is a forage crop established by stalks, weed interference differs from forage species established by seeds.

Another relevant aspect is the interference that certain weed species exerts with the grazing habit of animals. Pitelli (2014) reported that, although shrub and tree weeds reduce the incidence of light on forage grasses, these species do not provide much interference with pasture productivity because their root systems are deep. Thus, there is no total coincidence in the zone of soil exploitation with the forage plants, allowing green mass production for animal feeding.

Even if the pasture can produce green mass, the presence of some weed species may affect its use in certain places, preventing animals from accessing food. Some studies show that cattle avoid areas with large amounts of undesirable plants that do or do not have blunt or urticating structures (Williams, 1954; Cook, 1966; Senft, Rittenhouse, \& Woodmansee, 1985; Owens, Launchbaugh, \& Holloway, 1991).

More recently, Marchi et al. (2019a) also reported a surplus in actual grazing supply up to $15 \mathrm{~d}$ after the start of grazing, when cattle were placed to feed on pastures infested with 
Cnidoscolus urens L. (bull nettle), Dasyphyllum brasiliensis Spreng. (espinho-agulha), Zanthoxylum rhoifolium Lam. (prickly ash), and Luehea divaricata Mart. (açoita-cavalo). These researchers also reported that the animals avoided grazing in areas $1.50 \mathrm{~m}$ from the stem of the weeds and that the greatest forage surplus occurred in the vicinity of bull nettle plants compared with açoita-cavalo, which does not have any sharp or stinging structure. Therefore, weed negatively interferes with the grazing habit of the animals, and they avoid areas infested with plants that have blunt or stinging units, even if these areas contain a large supply of forage.

Another issue that has become increasingly important worldwide is animal protein production with low greenhouse gas (GHG) emissions. Animal production systems have increasingly received attention for contributing to increased GHG concentrations in the atmosphere, including methane $\left(\mathrm{CH}_{4}\right)$, carbon dioxide $\left(\mathrm{CO}_{2}\right)$, and nitrous oxide $\left(\mathrm{NO}_{2}\right)$. Emissions come from both enteric fermentation (which can be intensified by ingestion of forage with low nutritional value) and the deposition of excreta on pastures or the use of manure as fertilizer (storage and use) (Pinedo et al., 2009; Berchielli, Messana, \& Canesin, 2012). According to Monteiro et al. (2018), the emission of methane by ruminants is responsible for $22 \%$ of this gas in the atmosphere, constituting the third largest source on a global scale.

Within this context, Lourenço et al. (2019), Marchi et al. (2019b), and Meurer et al. (2020) conducted studies involving the presence of weeds in pasture areas. They reported that the longer the period of coexistence with weeds, the lower the leaf: stalk ratio, the higher the content of indigestible fiber, the lower the content of metabolizable and digestible energy, and consequently, the higher the potential for the in vitro GHG emission of $U$. ruziziensis, Panicum maximum Jacq Mombasa, and hybrid Urochloa. These researchers were unanimous in stating that simply removing weeds will not prevent GHG emissions from livestock production. However, when associated with other techniques, weed control can be an item to be considered within a strategy to mitigate GHG emissions in livestock production systems.

\section{Weed management}

One of the main issues related to weed control in Brazilian pastures is that few studies have addressed management techniques for these species, including alternatives to chemical control, either in natural or cultivated pastures. Additionally, it is important to highlight some assumptions based on the social culture of cattle farmers in several regions of Brazil. This is related to the way land occupation is conducted.

\section{Mechanical method}

As mentioned earlier, Brazilian Cerrado areas have a strong extractive influence on extensive livestock farming, with the main premise being to produce with little or no use of financial resources (Marchi et al., 2017; Marchi, Marques, Araújo, Silva, \& Martins, 2022). Thus, weed elimination by the mechanical method is still very common, either manually, using a sickle and hoe, or with equipment coupled to tractors, such as brush cutters, knife rollers, trail, links, or chains. The use of each type of 
equipment depends on the type of vegetation, size, infestation density, and labor availability in the region (Victória, Ladeira, Pelissari, Reis, \& Daltro, 2014). However, it should be noted that mechanical control alone is not enough to manage weeds in pastures because this method is not selective for forage species and is not efficient in eliminating and may even increase the infestation by species that are not part of the diet of livestock.

Brum, Purisco, Lemos and Riet-Correa (2002) studied the occurrence of intoxication by Vernonia rubricaulis Humb. \& Bonpl in cattle in several Mato Grosso do Sul farms and reported higher animal mortality in areas where weed control was used on the trail. However, there was no record of deaths in those areas where the equipment was not used. The researchers inferred that intoxication is caused by only cutting the plants on the trail and promoting the sprouting of $V$. rubricaulis, making it more attractive to grazing.

An example of a weed management strategy in degraded pastures is maintenance, commonly used to control weeds in areas with medium levels of degradation, performed by mechanical weeding with the use of equipment coupled to tractors and fertilization for forage tiller recovery (D. Souza, Fernandes, Silva, Santos, \& Silva, 2015). However, Pellegrini, Nabinger, Carvalho and Neumann (2007). Pellegrini, Nabinger, Neumann, Carvalho and Crancio (2010) and Fontoura et al. (2007) conducted studies in the Rio Grande do Sul and stated that this management technique, as a method of weed control in native pastures, is not capable of effectively controlling undesirable plants.

However, it is important to note that this method has the advantage of recovering the structure of the pasture by renewing the tiller population (Fontoura et al., 2007; D. Souza et al., 2015), besides producing a large amount of straw that eventually constitutes a physical barrier to the emergence of weed seedlings. After clearing the area, the accumulation of straw on the soil caused reduced germination of photoblastic positive seeds, and decreased the interference with seeds that require a large temperature range to begin the germination process. Furthermore, the emergence of seedlings from seeds with a small reserve may be impaired because the plant may not cross the deposited straw (Gomes, Bevilaqua, Silva, \& Monquero, 2014).

Marchi, Marques, Souza, Justo and Martins (2020), conducted a study in Barra do Garças, MT, and reported that seeds of Paspalum virgatum L. (sword grass), considered one of the main species of pasture weed in the center-western and northern regions of Brazil, have high vigor in seedling emergence provided they receive only an amount of $B$. brizantha straw less than 4.0 tha1. Because of this, the researchers suggested that the greater the amount of straw covering the seed, the lower the percentage of seedling emergence, thereby making cutting and leaving straw an effective method to control monocotyledonous weeds in pastures.

\section{Physical method}

It should also be noted that some weed control studies were based on old techniques that do not have scientifically proven results. For example, R. M. Souza, Teixeira and Almeida Torres (1985), in the municipality of Leopoldina/ $M G$, cited the use of fire as an effective alternative for controlling $l$. brasiliensis 
(satintail) in $M$. minutiflora (molasses grass) pastures. However, the researchers stated that among the methods researched, burning during pre-sowing was the least efficient, followed by plowing and the use of glyphosate herbicide during pre-sowing.

\section{Chemical method}

It is noteworthy that chemical weed control in pastures is the most widely used method to control these species, especially eudicotyledons. The weeds that are considered more difficult to control in pastures are the invasive grasses because of their morphological, physiological, and biochemical similarity with forage species and the lack of effective chemical control methods (Goulart, Nunes, Kupas, \& Merotto, 2012; Marques, Marchi, Pinheiro, Marques, \& Martins, 2019a). The main methods for applying herbicides in pastures are foliar application (spraying in total area or directed spray), cut stump application (spraying or brushing), basal application without cutting (spraying or brushing), and soil application.

\section{Selectivity}

The major concern regarding herbicides in pastures is the selectivity of the various active ingredients on the market for the numerous species of forage grasses. Based on data from the Ministry of Agriculture Livestock and Supply - MAPA (Ministério da Agricultura, Pecuária e Abastecimento, [MAPA] 2020), there are currently 203 products formulated in Brazil based on the 16 different active ingredients recommended for pasture weed control.
Brighenti, Calsavara and Varotto (2017), in Rio de Janeiro and Minas Gerais, evaluated the selectivity of the herbicides atrazine + S-metolachlor, atrazine + simazine, ametryn, ethoxysulfuron, S-metolachlor, diuron + hexazinone, sulfentrazone, and imazethapyr and atrazine at doses normally recommended in the package insert during the pre-emergence of elephant grass ( $P$. purpureum). These researchers concluded that the herbicides atrazine $+\mathrm{S}$-metolachlor, atrazine + simazine, ametryn, ethoxysulfuron, S-metolachlor, sulfentrazone, and atrazine did not cause phytotoxicity to elephant grass plants $35 \mathrm{~d}$ after treatment (DAT), being selective to the crop. However, diuron + hexazinone and imazethapyr were phytotoxic to elephant grass, resulting in up to 81 and $70 \%$ at 35 DAT, respectively.

When evaluating the selectivity of the herbicides 2,4-D (1,340.0 g e.a. ha-1), 2,4-D + picloram $\left(720.0+192.0\right.$ g e.a. ha ${ }^{-1}+0.3 \%$ $\mathrm{v} / \mathrm{v}$ nonionic adjuvant), fluroxypyr + picloram $(80.0+80.0$ g e.a. ha-1 $+0.3 \%$ v/v mineral oil), fluroxypyr + aminopyralid (160.0 + $80.0 \mathrm{~g}$ e.a. $\mathrm{ha}^{-1}+0.3 \% \mathrm{v} / \mathrm{v}$ mineral oil), fluroxypyr + triclopyr (320.0 + 960.0 g e.a. ha-1 $+0.3 \%$ v/v mineral oil), bentazon $(720.0 \mathrm{~g}$ i.a. ha-1 $+0.5 \% \mathrm{v} / \mathrm{v}$ mineral oil), imazapyr (25.0 g i.a. ha-1), monosodium acid methane arsenate (MSMA) $(1,440.0 \mathrm{~g}$ i.a. $\mathrm{ha}^{-1}+0.1 \% \mathrm{v} / \mathrm{v}$ nonionic adjuvant), atrazine + S-metolachlor $(1480.0+1,160.0 \mathrm{~g} \text { i.a. ha-1 })^{-1}$ and atrazine + tembotrione $(1,000.0+100.8 \mathrm{~g}$ i.a. $\mathrm{ha}^{-1}+0.3 \% \mathrm{v} / \mathrm{v}$ mineral oil) applied to postemergence African Bermuda grass (Cynodon nlemfuensis Vanderyst) in the state of Minas Gerais, Brighenti, Benites and Souza Sobrinho (2019) found that the most phytotoxic treatments for the species were fluroxypyr + amininopyralid, fluroxypyr + triclopyr, and atrazine + tembotrione, with a reduction of 
approximately 35,23 , and 55\%, respectively, for the variable dry matter of plants. The researchers also commented that the dry matter yield of African Bermuda-grass plants was not affected by the application of 2,4-D, 2,4-D + picloram, bentazon, imazapyr, MSMA, and atrazine + S-metolachlor, and these herbicides could be considered potential treatments in the management of African Bermuda-grass pastures.

Anésio et al. (2017) conducted a study in Diamantina, MG, to evaluate the selectivity of the herbicides nicosulfuron, clomazone, glyphosate, fluazifop-p-butyl + fomesafen, lactofen, fomesafen, fluazifopp-butyl, and mesotrione applied to two post-emergence forage species, $B$. decumbens Basilisk and $U$. ruziziensis, and reported that these herbicides were less intoxicating to Brachiaria plants than ruziziensis plants. However, nicosulfuron and glyphosate promoted greater intoxication to Brachiaria and ruziziensis plants compared to the other herbicides. The researchers added that the herbicides glyphosate, fluazifopp-butyl + fomesafen, fluazifop-p-butyl, mesotrione, and nicosulfuron affected the variable fluorescence/maximum fluorescence $(F v / F m)$ ratio in both species, indicating that these herbicides affected the photosynthetic apparatus. The results showed that both plants had greater susceptibility to the herbicides glyphosate, fluazifop-p-butyl + fomesafen, fluazifop-p-butyl, mesotrione, and nicosulfuron.

When evaluating the selectivity of the herbicides diuron (800.0 and 1,600.0 $\mathrm{g} \mathrm{ha}^{-1}$ ), ametryn (625.0 and 1,250.0 $\mathrm{g} \mathrm{ha}^{-1}$ ), imazaquin (75.0 and $150.0 \mathrm{~g} \mathrm{ha}^{-1}$ ), imazethapyr (50.0 and $100.0 \mathrm{~g} \mathrm{ha}^{-1}$ ), and flumetsulam (70.0 and 140.0 $\mathrm{g} \mathrm{ha}^{-1}$ ) applied pre-emergence of production and seed quality of $\mathrm{B}$. brizantha Marandú and
B. decumbens Basilisk grown in Botucatu, SP, Rodrigues-Costa et al. (2011) reported that the herbicides ametryn, imazaquin, imazethapyr, and flumetsulam provided greater selectivity to $B$. brizantha plants. In contrast, for $B$. decumbens, the herbicides diuron, ametryn, and imazethapyr were the most selective, highlighting diuron at the lowest dose studied $\left(800.0 \mathrm{~g} \mathrm{ha}^{-1}\right)$.

To study the selectivity of the herbicides diclofopmethyl (284.0 g ha $\left.^{-1}\right)$, ametryne $(1,250.0$ $\mathrm{g}$ ha-1), propanil $\left(3,600.0 \mathrm{~g} \mathrm{ha}^{-1}\right)$, chlorimuronethyl (15.0 $\left.\mathrm{g} \mathrm{ha}^{-1}\right)$, nicosulfuron (50.0 $\left.\mathrm{g} \mathrm{ha}^{-1}\right)$, bentazon (720.0 $\left.\mathrm{g} \mathrm{ha}^{-1}\right)$, and atrazine (3.000 $\mathrm{g} \mathrm{ha}^{-1}$ ) applied to post-emergence Panicum maximum Jacq plants, Tanzania and Mombaça cultivars, grown in Botucatu, SP, and their effects on seed quality, Trigueiro et al. (2007) reported that nicosulfuron was the herbicide that caused the most visual damage and reduced plant dry mass in both cultivars. For the Mombasa cultivar, all herbicides reduced seed yield but did not affect germination. For the Tanzania cultivar, all herbicides were selective and did not affect the production or physiological quality of seeds and were recommended for weed control in pastures for animal feed and seed production.

Machado et al. (2013) evaluated the selectivity of herbicides on the forage legume Trifolium repens $\mathrm{L}$. (white clover) during the phenological stage of expansion of the first trefoil in the state of Paraná. They found that white clover could be considered tolerant to the herbicides bentazon + imazethapyr, imazethapyr, bentazon, and 2,4-D, with these herbicides being considered selective for the culture. The application of these products caused phytotoxicity of less than 25\%, maintaining the dry mass production of the crop above $1,300.0 \mathrm{~kg} \mathrm{ha}^{-1}$. 


\section{Control}

Regarding the effectiveness of the chemical control of weeds in pastures, some studies mention the use of several herbicides in an attempt to control species, such as yellow elder (Passini \& Kranz, 1997; Mendes et al., 2016), Brachiaria grass (W. Silva, Vilela, Pereira, Ferreira, \& Ferreira, 2002; M. V. Santos et al., 2006), Acacia farnesiana (Willd.), Mimosa pteridophyte (Mart.) (Carmona, Araújo, \& Pereira, 2001), and assa-peixe (Rassini \& Coelho, 1994). A study by Passini and Kranz (1997) in Paraná analyzed the efficacy of herbicides to control yellow elder (Tecoma stans (L.) Juss. Ex Kunth) in pastures, and the authors reported that the formulation 2,4-D + picloram did not control this plant, with the presented sprouts being 0.74 to $1.21 \mathrm{~m}$ in height 5 months after treatment. However, the lowest dose of tebuthiuron ( $2.0 \mathrm{~g}$ i.a. plant-1) evaluated was efficient to control the plants within 9 months after application.

Mendes et al. (2016) also studied yellow elder control ( $T$. stans) in the pasture with localized applications of the herbicides triclopyr (4\%) and triclopyr (3\%), applied at the base of the plants; picloram (2\%), applied to the stump of the plants after cutting; and triclopyr + picloram $(1 \%+1 \%)$ and triclopyr + picloram $(2 \%+2 \%)$, applied at the base of the plants, and found that all herbicides provided control levels above $95 \%$ at 270 d after application, being more efficient than the treatment with shoot cutting because of the re-growth capacity of the plants. The researchers added that the herbicides damaged the pasture in the area immediately around the plants that received the application.

In another study, W. Silva et al. (2002) evaluated the use of herbicides to reduce weed interference with pastures cultivated with two elephant grass cultivars, Cameroon and Pioneiro, in Minas Gerais and recorded that the herbicides metolachlor and atrazine + metolachlor, applied during pre-emergence, were selective for the two cultivars tested. Regarding treatment with oxyfluorfen up to a dose of $0.96 \mathrm{~kg} \mathrm{ha}^{-1}$, the researchers stated that it was selective for forage crops in preand post-emergence applications. Amethryne, applied in post-emergence, was also selective for the cultivars at a dose of less than 2.50 $\mathrm{kg} \mathrm{ha}^{-1}$. B. decumbens and $B$. brizantha were efficiently controlled (90.9\%) during preemergence, except at the lowest dose of metolachlor and atrazine + metolachlor. The control of eudicotyledons in the study area reached $85 \%$ with the herbicides metolachlor, atrazine + metolachlor, and oxyfluorfen, except at the lowest doses of the products. The use of amethryne during post-emergence, at doses of 2.50 and $3.75 \mathrm{~kg} \mathrm{ha}^{-1}$, and oxyfluorfen, at the three doses studied, provided control greater than $90.3 \%$ for $B$. decumbens, B. brizantha, Sida glaziovii (K. Schum), and Sida urens (L.); however, oxyfluorfen provided control of $A$. australe and Desmodium tortuosum (Sw.) DC. of less than $81.0 \%$, and ametryne of less than $75.6 \%$ for $D$. tortuosum.

M. V. Santos et al. (2006) evaluated $B$. brizantha control using glyphosate after establishing Tifton 85 (Cynodon spp.) and reported control greater than $90 \%$ of $B$. brizantha from a dose of $738.28 \mathrm{~g} \mathrm{ha}^{-1}$ of glyphosate salt, whereas intoxication to Tifton 85 plants was only $12.05 \%$. At 60 DAT, there was reduced Brachiaria dry mass production from the dose of $90.0 \mathrm{~g} \mathrm{ha}^{-1}$. The researchers also highlighted the good tolerance of Tifton $85 \mathrm{up}$ to a dose of $720.0 \mathrm{~g} \mathrm{ha}^{-1}$ of glyphosate. 
In Goiás, Carmona et al. (2001) studied A. farnesiana and $M$. pteridofita control in pastures by brush application of diesel oil, used tractor lubricating oil, an aqueous solution of $2,4-D+$ picloram, and an oily solution of 2,4-D + picloram on the stump, reporting that cutting the plants was only efficient in controlling both species when applied at ground level and followed by the application of a specific herbicide, such as 2,4-D + picloram. The researchers commented that diesel oil also fully controlled both species at lower costs than 2,4-D + picloram, but only when applied to younger plants. However, there was an incompatibility between diesel oil and 2,4-D + picloram in controlling both species, and the used lubricating oil showed no herbicidal effect on adult plants of these species.

Rassini and Coelho (1994) evaluated the chemical control of assa-peixe ( $V$. polyanthes) in pastures in the state of São Paulo with the use of glyphosate in three doses and application modes on the shrub (on the cut stub at 8, 6, and 4\%; on the stem girdling at 20,15 , and $10 \%$; and on the shoot by spraying at 4,3 , and $2 \%$; and with the use of a mixture of $2.4 \mathrm{D}+4 \%$ pichloran on the stub $10 \%$ with girdling and $2 \%$ in foliar spray) and reported that glyphosate was efficient in the chemical control of assa-peixe only when applied to the shoot of the plant, in foliar spraying at 2,3 , and $4 \%$, being similar to $2,4-\mathrm{D}+$ picloram.

\section{Crop-livestock integration and crop rotation systems}

As a viable alternative for the effective control of weeds in degraded pastures, M. B. Dias (2011) added crop-livestock integration projects in the recovery of these pastures, highlighting that this grain production and livestock system integration is a viable option to intensify land use, increasing productivity levels and diversity in the farm. In addition, crop rotation systems using legumes can help intensify the recovery of degraded pasture areas and decrease the occurrence of weeds in the new pasture implementation. This occurs because the chemical control of weeds, which may occur in these areas with grain production for some years, is enhanced by using different herbicide molecules and broad-spectrum management.

However, it is important to emphasize that, regardless of the alternative weed control method in pastures (crop integration or rotation), several precautions must be taken when implementing these measures. For croplivestock integration or crop rotation system projects to be successful in a given area, all the cultural treatments conducted in previous years should be considered, especially those related to the use of herbicides, and the correct determination of the crop to be used subsequently or in consortium with the pasture. This is necessary because some active ingredients have the characteristic of persisting in the soil for long periods. According to Timossi et al. (2020), herbicides that have residual activity in the soil for a period longer than the life cycle may interfere with successive crops, and this effect is called a "carryover." When evaluating the residual effect of herbicides commonly applied in pastures (2,4-D, picloram, and picloram + $2,4-D)$ on soybean crops, these researchers concluded that the picloram and its mixture with 2,4-D negativelyaffected the development of soybean (NS 7300 IPRO) regarding the number of plants, and height and fresh and dry mass of plants. However, 2,4-D applied alone 
did not cause residual effects on soybean under the conditions studied, inferring that the application of picloram in pasture areas in previous years may compromise subsequent crops.

\section{Final considerations}

Adequately addressing the issue of weed occurrence in pasture areas is a crucial point and involves increased commitment in all sectors of the corporate livestock production chain. The main weed species occurring in pasture areas in Brazil vary according to type, quality, age, and forage management and have the ruderal characteristics of withstanding high-intensity disturbance, such as intense grazing, fire, and weeding but with low-stress intensity. Because of the vast national territory, few scientific articles can define the main weed species and their coverage in terms of regions and micro-regions.

The main weed interference with pasture areas refers to the decreased productive capacity of the forage, changed forage anatomy (mainly affecting the leaf: stalk ratio), decreased nutritional quality of forage and digestible and metabolizable energy level, and increased potential for GHG emissions, amount of indigestible fiber, and the altered ingestion behavior of animals because of difficult access to forage. Chemical control by applying specific and regularly registered herbicides selective for pastures is practically the only control of eudicotyledonous weeds. There are practically no scientific studies providing information on the control of monocotyledonous weeds or even other alternative methods to chemical control, such as mechanical or physical methods.

\section{References}

Andrade, R. G., Bolfe, É. L., Victoria, D. C., \& Nogueira, S. F. (2017). Avaliação das condições de pastagens no cerrado brasileiro por meio de geotecnologias. Revista Brasileira de Agropecuária Sustentável (RBAS), 7(1), 34-41. doi: 10.21206/rbas.v7i1.376

Anésio, A. H. C., Santos, M. V., Silveira, R. R., Ferreira, E. A., Braz, T. G. S., Tuffi Santos, L. D., \& Santos, J. B. (2017). Herbicide selectivity to signal grass and congo grass. Planta Daninha, 35, e017157521. doi: 10.1590/ s0100-83582017350100062

Araújo, P. P. S., Marques, R. F., Pinheiro, G. H. R., Souza, R. M., \& Marchi, S. R. de. (2020). Guinea grass yield under interference of monocotyledon weeds. Communications in Plant Sciences, 10, cps2020013. doi: $10.26814 /$ cps2020013

Bellé, J. R., Marchi, S. R., Martins, D., Sousa, A. C., \& Pinheiro, G. H. R. (2018). Nutritional value of Marandú palisade grass according to increasing coexistence periods with weeds. Planta Daninha, 36, e018170348. doi: 10.1590/s0100-8358 2018360100070

Berchielli, T. T., Messana, J. D., \& Canesin, R. C. (2012). Produção de metano entérico em pastagens tropicais. Revista Brasileira de Saúde e Produção Animal, 13(4), 954-968. doi: 10.1590/S1519-99 402012000400010

Brandão, M., Paluma, E., Kein, V. L., Mautone, L., Guimarães, E. F., Pereira, R. C., \& Miguel, J. R. (1995). Plantas daninhas do Estado do Rio de Janeiro: acréscimo aos trabalhos já efetuados no Estado. Planta Daninha, 13(2), 98-116. doi: 10.1590/S0100-8358 1995000200005 
Braun Blanquet, U. J. (1979). Fitossociologia. Base para el estúdio de las comunidades vegetales. Madrid: $\mathrm{H}$. Blume Ediciones.

Brighenti, A. M., \& Oliveira, M. F (2018). Periods of interference by Cyperus esculentus L. in Pennisetum purpureum Schum. Acta Agronómica, 67(4), 512-516. doi: 10.15446/acag.v67n4.69985

Brighenti, A. M., Benites, F. R. G., \& Souza Sobrinho, F. (2019). African star grass response to postemergence herbicides. Ciência e Agrotecnologia, 43, e026918. doi: 10.1590/1413-7054201943026918.

Brighenti, A. M., Calsavara, L. H. F., \& Varotto, Y. V. G. (2017). Preemergence herbicides on weed control in elephant grass pasture. Ciência e Agrotecnologia, 41(1), 52-59. doi: 10.1590/1413-70542017411024516

Brum, K. B., Purisco, E., Lemos, R. A., \& RietCorrea, F. (2002). Intoxicação por Vernonia rubricaulis em bovinos no Mato Grosso do Sul. Pesquisa Veterinária Brasileira, 22(3), 119-128. doi: 10.1590/S0100-736X 2002000300006

Carmona, R., Araujo, B. S. C., Neto, \& Pereira, R. C. (2001). Control of Acacia farnesiana and of Mimosa pteridofita in pastures. Pesquisa Agropecuária Brasileira, 36(10), 1301-1307. doi: 10.1590/S0100204X2001001000013

Carvalho, P. C. F., Santos, D. T., \& Neves, F. (2007). Oferta de forragem como condicionadora da estrutura do pasto e do desempenho animal. In M. Dall'Agnol, C. Nabinger, D. M. Santana, \& R. J. Santos (Orgs.), Sustentabilidade produtiva do bioma pampa (pp. 23-60). Porto Alegre: Gráfica Metrópole Ltda.

Carvalho, R. M., Pimentel, R. M., Fonseca, D. M., \& Santos, M. E. (2016). Effects of weed plants on tiller characteristics in brachiaria pasture. Boletim de Indústria Animal, 73(2), 103-110. doi: 10.17523/bia.v73n2p103
Carvalho, S. L., \& Pitelli, R. A. (1992). Levantamento e análise fitossociológica das principais espécies de plantas daninhas depastagens daregião deSelvíria (MS). Planta Daninha, 10(1-2), 25-32. doi: 10.1590/S0100-83581992000100001

Carvalho, T. B., \& De Zen, S. (2017). A cadeia de pecuária de corte no Brasil: evolução e tendências. Revista iPecege, 3(1), 85-99. doi: 10.22167/r.ipecege.2017.1.85

Carvalho, W. T. V., Minighin, D. C., Gonçalves, L. C., Villanova, D. F. Q., Mauricio, R. M., \& Pereira, R. V. G. (2017). Pastagens degradadas e técnicas de recuperação: revisão. Pubvet, 11(10), 947-1073. doi: 10.22256/PUBVET.V11N10.1036-1045

Cook, C. W. (1966). Factors affecting utilization of mountain slopes by cattle. Journal of Range Management, 19(4), 200-204. doi: $10.2307 / 3895647$

Dantas, M. (1979). Pastagens da Amazônia Central: ecologia e fauna do solo. Acta Amazonica, 9(2), 5-54. doi: 10.1590/180943921979092s005

Dias, M. B., Fo. (2011). Os desafios da produção animal em pastagens na fronteira agrícola brasileira. Revista Brasileira de Zootecnia, 40(Supl. Esp.), 243-252.

Dias, M. B., Fo. (2016). Manejo da pastagem para uma pecuária empresarial. Anais do II Simpósio de pecuária integrada, Recuperação de pastagens. Cuiabá, MT: Uniselva. (pp. 36-53). Recuperado de https://ainfo.cnptia.embrapa.br/digital/ bitstream/item/149037/1/Dias-Filho-MBPecuaria-empresarial-2016.pdf

Dias, R. C., Santos, M. V., Ferreira, E. A., Braz, T. G. S., Figueiredo, L. V., Cruz, P. J. R., \& Silva, L. D. (2018). Phytosociology in degraded and renewed pastures in agrosilvopastoral systems. Planta Daninha, 36, e018174800. doi: 10.1590/ s0100-83582018360100075 
Fontoura, J. A. S. D., Jr., Carvalho, P. C. D. F., Nabinger, C., Silva, J. L. S. D., Pinto, C. E., \& Crancio, L. A. (2007). Produção animal em pastagem nativa submetida ao controle de plantas indesejáveis e a intensidades de pastejo. Ciência Rural, 37(1), 247-252. doi: 10.1590/S0103-84782007000100040

Galvão, A. K. D. L., Silva, J. F. D., Albertino, S. M. F., Monteiro, G. F. P., \& Calvalcante, D. P. (2011). Levantamento fitossociológico em pastagens de várzea no Estado do Amazonas. Planta Daninha, 29(1), 6975. doi: 10.1590/S0100-835820110001 00009

Gléria, A. A., Silva, R. M., Santos, A. P. P., Santos, K. J. G., \& Paim, T. P. (2017). Produção de bovinos de corte em sistemas de integração lavoura pecuária. Archivos de Zootecnia, 66(253), 141-150. doi: 10. 21071/az.v66i253.2138

Gomes, D. S., Bevilaqua, N. C., Silva, F. B., \& Monquero, P. A. (2014). Supressão de plantas espontâneas pelo uso de cobertura vegetal de crotalária e sorgo. Revista Brasileira de Agroecologia, 9(2), 206-213.

Goulart, I. C. G. D. R., Nunes, A. L., Kupas, V., \& Merotto, A., Jr. (2012). Interações entre herbicidas e protetores para o controle de capim-annoni em pastagem natural. Ciência Rural, 42(10), 1722-1730. doi: 10.1590/S0103-84782012001000002.

Grime, J. P. (1979). Plant strategies, vegetation processes, and ecosystem properties (2nd ed.). Chichester: John Wiley \& Sons Ltd.

Harper, J. L. (1977). Population biology of plants. London: Academic Press.

Lara, J. F. R., Macedo, J. F., \& Brandão, M. (2003). Plantas daninhas em pastagens de várzeas no Estado de Minas Gerais.
Planta Daninha, 21(1), 11-20. doi: 10.1590/ S0100-83582003000100002

Lourenço, A. A., Mota, R. V., Sanches, J. L., Marques, R. F., \& Marchi, S. R. (2019). Weed interference in the establishment of Urocloa ruziziensis. Planta Daninha, 37, e019184957. doi: 10.1590/s010083582019370100077

Machado, D., Lustosa, S. B. C., Baldissera, T. C., Turok, J. D. N., Machado, M., Watzlawick, L. F.,... Pelissari, A. (2013). Seletividade de herbicidas em trevo-branco no estádio fenológico de expansão do primeirotrifólio. Ciência Rural, 43(12), 2132-2138. doi: 10.1590/S0103-84782013001200002

Marchi, S. R., Bellé, J. R., Foz, C. H., Ferri, J., \& Martins, D. (2017). Weeds alter the establishment of Brachiaria brizantha cv. Marandu. Tropical Grasslands-Forrajes Tropicales, 5(2), 85-93. doi: 10.17138/ $\operatorname{tgft}(5) 85-93$

Marchi, S. R., Marques, R. F., Araújo, P. P. S., Silva, I. T. D., \& Martins, D. (2022). Weed interference in Marandu palisade grass pastures under renewal or maintenance conditions. Revista Brasileira de Engenharia Agrícola e Ambiental, 26(3), 166-172. doi: 10.1590/1807-1929/ agriambi.v26n3p166-172

Marchi, S. R., Marques, R. F., Souza, R. M., Justo, C. F., \& Martins, C. C. (2020). Straw interference in the emergence of talquezal seeds from different origins. Planta Daninha, 38, e020223128. doi: 10.1590/ s0100-83582020380100059

Marchi, S. R., Silva, H. M., Ferreira, C. F., Marques, R. F., \& Moraes, J. B. (2019a). Interference of noxious shrubs on grazing behavior by bovines. Planta Daninha, 37, e019185644. doi: 10.1590/s0100-8358 2019370100009 
Marchi, S. R., Sousa, A. C., Marques, R. F., Pinheiro, G. H. R., Souza, R. M., \& Martins, D. (2019b). Potential of greenhouse gas production by guinea grass subjected to weed competition. Journal of Agricultural Science, 11(8), 257-272. doi: 10.5539/jas. v11n8p257

Marques, A. S., Marchi, S. R., Pinheiro, G. H. R., Marques, R. F., \& Martins, C. C. (2019a). Emergence of razor grass on the basis of origin and seed depth in the soil profile. Planta Daninha, 37, e019214034. doi: 10. 1590/s0100-83582019370100126

Marques, R. F., Marchi, S. R. de, Santos Araújo, P. P. dos, Pinheiro, G. H. R., Queiroz, B. B. T., \& Silva, A. A. S. (2019b). Interferência de plantas daninhas na formação de pastagem com capim Vaquero. Acta Iguazu, 8(4), 107-120. doi: 10.48075/ actaiguaz.v8i4.21477

Martins, C. C., Martins, D., Negrisoli, E., \& Stanguerlim, H. (2000). Comportamento germinativo de sementes de leiteiro (Peschiera fuchsiaefolia): efeito da temperatura e luz. Planta Daninha, 18(1), 85-91. doi: 10.1590/S0100-8358200000 0100009

Martins, P. F. R. B., Yamauti, M. S., \& Alves, P. L. C. A. (2018). Interference between signal grass and cinderella weed. Planta Daninha, 36, e018151776. doi: 10.1590/ s0100-83582018360100081

Mascarenhas, M. H. T., Viana, M. C. M., Lara, J. F. R., Botelho, W., \& Morel, F. (2009). Flora infestante em pastagem degradada sob recuperação, pelo sistema de integração lavoura-pecuária, em região de cerrado. Revista Brasileira de Milho e Sorgo, 8(1), 41-55. doi: 10.18512/1980-6477/rbms.v8 $n 01 p \% 25 p$

Mascarenhas, R. E., Modesto, M. D. S., Jr., Dutra, S., Souza, A. P. D. S., Fo., \& Teixeira,
J. F., Neto. (1999). Plantas daninhas de uma pastagem cultivada de baixa produtividade no nordeste paraense. Planta Daninha, 17(3), 399-418. doi: 10. 1590/S0100-83581999000300008

Mendes, R. R., Biffe, D. F., Constantin, J., Oliveira, R. S. de, Jr., Rosa, Ê. L., Cuba, A. L. F., \& Baladeli, R. B. (2016). Controle de amarelinho (Tecoma stans) em pastagem com aplicações localizadas de herbicidas. Revista Brasileira de Herbicidas, 15(4), 303-312. doi: 10.7824/rbh.v15i4.488

Meurer, E., Brito, S. C., Marchi, S. R., Pinheiro, G. H. R., \& Martins, D. (2020). Potential of methane and carbon dioxide in vitro production by Urochloa hybrid subjected to periods of coexistence with weeds. Bioscience Journal, 36(3), 768-782. doi: 10.14393/BJ-v36n3a2020-47709

Mezzalira, J. C., Carvalho, P. C. D. F., Fonseca, L., Bremm, C., Reffatti, M. V., Poli, C. H. E. C., \& Trindade, J. K. D. (2011). Aspectos metodológicos do comportamento ingestivo de bovinos em pastejo. Revista Brasileira de Zootecnia, 40(5), 11141120. doi: 10.1590/S1516-35982011000 500024

Ministério da Agricultura, Pecuária e Abastecimento (2020). Agrofit - Consulta de produtos formulados. Recuperado de http://agrofit.agricultura.gov.br/agrofit_ cons/principal_agrofit_cons

Modesto, M. S, Jr., \& Mascarenhas, R. E. B. (2001). Levantamento da infestação de plantas daninhas associada a uma pastagem cultivada de baixa produtividade no Nordeste Paraense. Planta Daninha, 19(1), 11-21. doi: 10.1590/ S0100-83582001000100002

Monteiro, A. L. G., Faro, A. M. C. D. F., Peres, M. T. P., Batista, R., Poli, C. H. E. C., \& Villalba, J. J. (2018). The role of small ruminants on 
global climate change. Acta Scientiarum. Animal Sciences, 40, e43124. doi: 10.40 25/actascianimsci.v40i1.43124

Mueller-Dombois, D., \& Ellenberg, D. (1974). Aims and methods of vegetation ecology. New York: Wiley.

Owens, M. K., Launchbaugh, K. L., \& Holloway, J. W. (1991). Pasture characteristics affecting spatial distribution of utilization by cattle in mixed brush communities. Rangeland Ecology \& Management/ Journal of Range Management Archives, 44(2), 118-123. doi: 10.2307/4002308

Parente, L., Mesquita, V., Miziara, F., Baumann, L., \& Ferreira, L. (2019). Assessing the pasturelands and livestock dynamics in Brazil, from 1985 to 2017: a novel approach based on high spatial resolution imagery and Google Earth Engine cloud computing. Remote Sensing of Environment, 232, 111301. doi: 10.1016/j.rse.2019.111301

Passini, T., \& Kranz, W. M. (1997). Eficácia de herbicidas no controle de amarelinho (Tecoma stans) em pastagem. Planta Daninha, 15(2), 190-197. doi: 10.1590/ S0100-83581997000200012

Peixoto, A. L., Carvalho, S. M., \& Rosa, M. M. T. da. (1982). Análise botânica de um campo de pastagem no estado do Rio de Janeiro. Planta Daninha, 5(2), 1-7. doi: 10.1590/ S0100-83581982000200001

Pellegrini, L. G. D., Nabinger, C., Carvalho, P. C. D. F., \& Neumann, M. (2007). Diferentes métodos de controle de plantas indesejáveis em pastagem nativa. Revista Brasileira de Zootecnia, 36(5), 1247-1254. doi: 10.1590/S151635982007000600005

Pellegrini, L. G. D., Nabinger, C., Neumann, M., Carvalho, P. C. D. F., \& Crancio, L. A. (2010). Produção de forragem e dinâmica de uma pastagem natural submetida a diferentes métodos de controle de espécies indesejáveis e à adubação. Revista Brasileira de Zootecnia, 39(11), 2380-2388. doi: 10.1590/S1516-359820 10001100010

Pereira, M. F. V. (2015). A modernização recente da pecuária bovina em Rondônia: normas territoriais e a nova produtividade. Revista Geo UERJ, 26, 95-112. doi: 10.12957/ geouerj.2015.13534

Pinedo, L. A., Jacomini, A., Vendramin, D., Nolasco, F., Lauro Jr., Santos, M. A., \& Selem, A. S. M. A. (2009). Inventário de emissões de gás metano provenientes da fermentação entérica e óxido nitroso do manejo de dejetos animais-período 1990 a 2005. Pubvet, 3(11), 1-7.

Pitelli, R. A. (1985). Interferência de plantas daninhas em culturas agrícolas. Informe Agropecuário, 11(129), 16-27.

Pitelli, R. A. (2014). Competição entre plantas daninhas e plantas cultivadas. In P. A. Monquero, Aspectos da biologia e manejo das plantas daninhas (pp. 61-81). São Carlos: RiMa Editora.

Pitelli, R. A., \& Bianco, S. (2013). Avaliações de índicesfitossociológicos emcomunidades infestantes de agroecossistemas. In J. F. Silva, D. Martins (Eds.), Manual de aulas práticas de plantas daninhas (pp. 1-8). Jaboticabal, SP: Funep.

Pitelli, R. A., \& Durigan, J. C. (1984). Terminologia para períodos de controle e de convivência das plantas daninhas em culturas agrícolas. Anais do Congresso Brasileiro de Herbicidas e Plantas Daninhas, Belo Horizonte, MG, Brasil, 15.

Pitelli, R. A., \& Pitelli, R. L. C. M. (2004). Biologia e Ecofisiologia das plantas daninhas. In L. Vargas, \& E. S. Roman, Manual de manejo e controle de plantas daninhas (pp. 29-55). Bento Gonçalves: EMBRAPA. 
Rassini, J. B., \& Coelho, R. R. (1994). Controle químico de assa-peixe (Vernonia polyanthes) em pastagens. Revista Brasileira de Zootecnia, 23(6), 1994-6871.

Rodrigues-Costa, A. C. P., Martins, D., Costa, N. V., Campos, C. F., Martins, C. C., Pereira, M. R. R., \& Silva, J. I. C. (2011). Seletividade de herbicidas aplicados em pré-emergência em gramíneas forrageiras. Planta Daninha, 29(3), 625-633. doi: 10.1590/S0100-83 582011000300017

Santos, M. C., Belik, W., De Zen, S., \& Almeida, L. H. (2014). A rentabilidade da pecuária de corte no Brasil. Segurança Alimentar e Nutricional, 21(2), 505-517. doi: 10.20396/ san.v21i2.8634589

Santos, M. E. R. (2011). Variabilidade espacial da vegetação e produção animal em pastagem monoespecífica: proposta de um modelo conceitual. Revista Brasileira de Agropecuária Sustentável, 1(1), 129136. doi: 10.21206/rbas.v1i1.22

Santos, M. V., Ferreira, E. A., Fonseca, D. M. D., Ferreira, L. R., Santos, L. D. T., \& Silva, D. V. (2015). Levantamento fitossociológico e produção de forragem em pasto de capimgordura. Revista Ceres, 62(6), 561-567. doi: 10.1590/0034-737X201562060008

Santos, M. V., Freitas, F. C., Ferreira, F. A., Viana, R. G., Tuffi Santos, L. D., \& Fonseca, D. M. (2006). Eficácia e persistência no solo de herbicidas utilizados em pastagem. Planta Daninha, 24(2), 391-398. doi: 10.1590/ S0100-83582006000200024

Senft, R. L., Rittenhouse, L. R., \& Woodmansee, R. G. (1985). Factors influencing patterns of cattle grazing behavior on shortgrass steepe. Rangeland Ecology \& Management/Journal of Range Management Archives, 38(1), 82-87. doi: $10.2307 / 3899341$
Silva, A., Santos, F. L. S., Barretto, V. C. M., Freitas, R. J., \& Kluthcouski, J. (2018). Recuperação de pastagem degradada pelo consórcio de milho, Urochloa brizantha cv. Marandu e guandu. Journal of Neotropical Agriculture, 5(2), 39-47. doi: 10.32404/rean.v5i2.1382

Silva, W., Vilela, D., Pereira, A. V., Ferreira, F. A., \& Ferreira, R. P. (2002). Redução da interferência de Brachiaria decumbens na formação de pastagem com Penisetum purpureum através de herbicidas. Planta Daninha, 20(2), 273-281. doi: 10.1590/ S0100-83582002000200014

Souza, D., Fernandes, W., Silva, G., Santos, M. E., \& Silva, S. (2015). A roçada do capimmarandu alto no fim do inverno melhora a estrutura do pasto no início do verão. Enciclopédia Biosfera, 11(21), 12-22.

Souza, R. M., Teixeira, N. M., \& Almeida Torres, R. de. (1985). Métodos de controle do sapê em pastagem de capim-gordura. Pesquisa Agropecuária Brasileira, 20(8), 963-967.

Strassburg, B. B. N., Latawiec, A. E., Barioni, L. G., Nobre, C. A., Silva, V. P., Valentim, J. F.,... Assad, E. D. (2014). When enough should be enough: Improving the use of current agricultural lands could meet production demands and spare natural habitats in Brazil. Global Environmental Change, 28, 84-97. doi: 10.1016/j. gloenvcha.2014.06.001

Teixeira, E. A., Marques, J. A., Silva, F. F., \& Pires, A. J. V. (2010). Feeding behavior and cattle displacement pattern in tropical pastures. Archivos de Zootecnia, 59, 57-70. doi: 10.21071/az.v59i232.4907

Teixeira, J. C., \& Hespanhol, A. N. (2014). A trajetória da pecuária bovina brasileira. Caderno Prudentino de Geografia, 36(1), 26-38. 
Teixeira, L. B., Canto, A. C., \& Homma, A. K. O. (1973). Controle de ervas invasoras em pastagens na Amazônia Ocidental. Manaus: IPEAAOc. (Circular IPEAAOc, 3).

Terra, A. B. C., Florentino, L. A., Rezende, A. V. D., \& Silva, N. C. (2019). Leguminosas forrageiras na recuperação de pastagens no Brasil. Revista de Ciências Agrárias, 42(2), 11-20. doi: 10.19084/rca.16016

Timossi, P. C., Gazarini, A. M., Queiroz, B. B. T. Gonçalves, D. C., Almeida, D. P., Araújo, R. O. B. de, \& Teixeira, I. R. (2020). Efeito residual de herbicidas auxínicos em soja. Revista Brasileira de Herbicidas, 19(3), e699. doi: 10.7824/rbh.v19i3.699

Trigueiro, L. R. C., Martins, D., Domingos, V. D., Martins, C. C., Terra, M. A., \& Cardoso, L. A. (2007). Seletividade de herbicidas aplicados em pós-emergência sobre capim-colonião e efeito na qualidade das sementes. Planta Daninha, 25(2), 341-349. doi: 10.1590/S0100-83582007 000200014
Tuffi Santos, L. D., Santos, I. C., Oliveira, C. H., Santos, M. V., Ferreira, F. A., \& Queiroz, D. S. (2004). Levantamento fitossociológico em pastagens degradadas sob condições de várzea. Planta Daninha, 22(3), 343-349. doi: 10.1590/S0100-83582004000300003

Victória, R., Fo., Ladeira, A., Neto, Pelissari, A., Reis, F. C., \& Daltro, F. P. (2014). Manejo sustentável de plantas daninhas em pastagens. In P. A. Monquero, Manejo de plantas daninhas nas culturas agrícolas (pp. 179-207). São Carlos: RiMa Editora.

Williams, R. E. (1954). Modern methods of getting uniform using of range. Journal of Range Management, 7(2), 77-81. doi: $10.2307 / 3893862$

Zanine, A. M., Vieira, B. R., Ferreira, D. J., Vieira, A. J. M., \& Cecon, P. R. (2007). Comportamento ingestivo de bovinos de diferentes categorias em pastagem de capim coast-cross. Bioscience Journal, 23(3), 111-119. 
